\title{
STUDENTS' PERCEPTIONS OF LEARNING SCIENCE IN SMALL GROUPS: A CASE STUDY IN HIGHER EDUCATION
}

S M Hafizur Rahman, Institute of Education and Research, University of Dhaka, Bangladesh, <Hafiz.Rahman@Education.monash.edu.au>

Md. Mahbub Alam Sarkar, Faculty of Education, Monash University, Melbourne, Australia, <Mahbub.Sarkar@Education.monash.edu.au>

Jui Judith Gomes, Melbourne Graduate School of Education, The University of

Melbourne, Australia, <j.gomes@pgrad.unimelb.edu.au>

Foez Ahmed Mojumder, Institute of Education and Research, University of Dhaka, Bangladesh, <foez_02@yahoo.com>

This study explores science students' perceptions about the nature of ongoing small group activities at the Institute of Education and Research [IER], University of Dhaka in Bangladesh. In this paper, we examine a range of influencing factors in small group learning, such as group composition, group norms, group tasks and students' participation with respect to students' preferred group learning approach. To address these issues, this study employed a mixed model research design where both quantitative and qualitative data were collected concurrently through a questionnaire from 166 volunteer Science Education students of IER. The findings of this study have implications for the concerns of both teachers and students of IER in order to improve their understanding of learning within small groups that characterize different approaches, norms and discourse towards an effective group work.

\section{Introduction}

Learning science in small groups is one of the current issues in science education (Hackling, 2003). Many courses in higher education involve in small group work for presenting, discussing, and/or presenting assignment or project work. The Institute of Education and Research [IER] at the University of Dhaka, the apex institution of teaching and researching Education in Bangladesh, is also currently practicing group work for both its Bachelor of Education (Honors) and Master of Education Programs (The Curriculum Committee, 2006). In particular, students from the Science Education group of IER are primarily involved in group work for preparing their assignments, project works and class presentations for different academic elective science courses, such as Physics, Chemistry and Biology. 
Recent studies have suggested that there are several compelling reasons that can make learning in a small group more effective (Blumenfeld, Marx, Soloway, \& Krajcik, 1996; Brewer \& Klein, 2006; Johnson \& Johnson, 1999). There are different approaches in group work and a particular approach of small group works effectively to achieve a particular type of learning outcome. The effectiveness of group work can be influenced by how the group is organised, what the tasks are, who the participants are and how the group is held accountable (Blumenfeld, et al., 1996). Besides, participants often play certain roles and develop or practice some social skills in working within a small group to make learning more effective. Also different types of discourse and cognitive processes occur in small group work that make group learning more productive (Hackling, 2003).

However, being closely involved in the teaching-learning processes of IER Science Education, we have experienced that in many cases, students are not satisfied in working within a group. For example, as students, we found very few groups work actively. We also noticed that in many cases, all members within a group did not participate equally. Consequently, one or two students had to do the entire task from a group of 4/5 students, however a single grade went to the group; hence the student who actually did the task and those who did not contribute at all, got the same grade in the end. This often created dissatisfaction among some of the group members. Also, sometimes students were not satisfied with the task they were assigned to or the organization of the group.

These experiences have triggered our thinking about the nature of science learning in small groups at IER. As our collective experiences suggest, students are not satisfied with group work; we aim to listen to the students' voice in this respect. Therefore, this study intends to explore the nature of science learning within a small group from students' perspectives. Also, to the best of our knowledge, there is no research regarding small group science learning in Bangladesh; this is the first such initiative. Thus, this research may make a significant contribution in current understanding of the students' views about the issue. This research will inform teachers and other related personnel of IER and other higher educational institutions about students' perceptions of learning science in small groups, which may in turn contribute to maintain quality science education.

\section{Theoretical Background}

This section covers Approaches in Group Learning and Factors influencing group work

\section{Approaches in Group Learning}

Group learning engages students in discussing a task with each other. Different small groups like to work using different approaches. Linn and Burbules (1993) identified two approaches in small group work: cooperative approach and collaborative approach. According to Linn and Burbules, "cooperative learning involves dividing a task into parts and having each group member complete one of the parts. In collaborative learning two or more students jointly work out a single solution to a problem" (p. 92). Students might choose any of these approaches.

Johnson and Johnson (1999) argued that when students work cooperatively to achieve a common goal, they produce higher achievement and demonstrate greater output than they do working single-handedly. This practice also produces greater psychological health, higher self-esteem, and greater social competencies. Johnson and Johnson (1999) also argued that cooperative group work makes students learn "how to communicate effectively, provide leadership, help the group make good decisions, build trust, repair hurt feelings, and 
understand other's perspectives" (p. 73). Thus cooperative group learning might benefit students diversely.

Research studies support that collaborative approach helps to enhance student's intrinsic motivation, persistence with adversity, and ability to transfer the knowledge and skills (Kapp, 2009; Pfaff \& Huddleston, 2003). Also, learning through collaborative approach helps learners to improve their communication skills, problem-solving abilities and capability to work as effective team members (Dickinson, 2000; Millis \& Cottell, 1998; Thomas \& Busby, 2003). Crook (1994) classified three cognitive benefits of collaborative group work - articulation, conflict and co-construction. Hackling (2003) explained this as participants need to articulate their ideas and understandings to clarify and make it explicit for working with a task collaboratively, which often leads to conflict between peers. This conflict requires participants to reflect, justify, modify or even abandon their understanding and positions in favor of a more practical clarification or solution. This notion of coconstruction is also supported by the idea of constructivist learning (Driver, Leach, Millar, \& Scott, 1996).

\section{Factors Influencing Group Work}

Different factors have been reported to influence students' activities in a group. Blumenfeld et al. (1996) pointed that educators must consider group composition, group norms, tasks and nature of participation as factors influencing the quality of learning within a group. The following sections discuss with these factors.

Group Composition. Group composition, which often relates to students' characteristics, is an important factor to the quality of learning within a group (Blumenfeld, et al., 1996; Hendry, et al., 2005; Houldsworth \& Mathews, 2000; Kempa \& Ayob, 1995). Students' characteristics may include their academic competence, achievement and personality. Research shows that a group formed with different abilities and personalities is more effective at decision making than a homogenous group (Brown \& Atkins, 1991; Duek, 2000). However, a group may not be successful if it includes high and low-ability students, because in this composition, high-ability students may dominate the group discussion, while low-ability students may lack necessary skills and misinterpret the task as well (Blumenfeld, et al., 1996). Blumenfeld, et al. therefore suggest that for optimal effectiveness, three types of composition for effective group learning would work: a group with high and mid-abilility students, a group with mid and low-abilility students, and a group with all mid-abilility students.

Group Norms. Effective group work requires students to share ideas, take risks, differ with and listen to others, and generate and organize points of view (Blumenfeld, et al., 1996). These norms play roles to work effectively in a group. It is noteworthy that just placing students in a group does not ensure a productive output; many problems may arise when students are involved in group activities (Blumenfeld, et al., 1996). "Free riding", engaging in "social loafing" and "hijacking" are common problems in this respect (Kapp, 2009, p. 139). This results some members in the group try to control or aggressively direct the group activities (Pfaff \& Huddleston, 2003). In these cases, as Blumenfeld, et al. (1996) suggest, group norms which include listening and resolving conflicts, appreciating the skills and abilities of others, and using rewards that promote interdependency among the members may play a significant role. 
Group Task. It also has an influence on effective group work. When students work with a problem in a group, extensive discussion and elaborative responses are required for helping peers understand their perspectives. Students often enjoy real life-oriented problems, which have more than one right answer and include students' creativity (Blumenfeld, et al., 1996; Carlsmith \& Cooper, 2002). "Social loafing" can be reduced by permitting students in selecting their own project for the group ensuring that the task requires a unique and original solution (Carroll, 1986; Harkins \& Petty, 1982). At the same time, students often need considerable guidance in the process of argumentation and offer justification for their reasoning (Palincsar, Anderson, \& David, 1993; Webb \& Mastergeorge, 2003).

Student Participation. Students' participation in group work often relates to individual accountability. Individual accountability ensures that one student does not do the group's entire work (Johnson \& Johnson, 1999). In order to ensure every student's accountability, individual performance may be counted regardless of the group performance (Blumenfeld, et al., 1996).

Students' participation may also refer to the nature of interaction within a group. For example, students' interaction within collaborative learning varies widely between groups and between occasions for the same group. More specifically, it depends on the discourse of the group. Damon and Phelps (1989) developed two indices in this regard: equality and mutuality of the engagement. Equality of engagement indicates the extent to which group members participate equally or unequally to the task, while mutuality of engagement indicates the extent to which discourse is extensive and connected (Hackling, 2003).

Further, Hackling (2003) divided students' interaction within a group into three categories: symmetric, asymmetric and shifting asymmetric. Symmetric interactions involve all members of the group through a collaborative or adversarial mode. In the collaborative mode, one participant adds or elaborates the understanding shared by another participant, while the adversarial mode involves confrontation and argumentation between students who do not share the same understanding. On the other hand, in asymmetric interactions, group members do not participate equally. This usually happens when the teacher joins with the group and talks with only one group member. However, in shifting asymmetric interaction, each student plays a dominant role for a given time, but for a longer period, one's participation is equal with that of the others.

Moreover, to ensure every member's participation, individual's role may be specified, which often influences the collaborative approach (Hackling, 2003). According to Hackling, these group roles could be "manager", "speaker" and "director" as a tool to organize and manage group work. In some cases, for large groups, a fourth role of "reporter" can be introduced. Besides, some social roles for group members may also emerge, such as "leader", "helper", "active non-contributor" and "passive non-contributor" (Richmond \& Striley, 1996). Leadership style also influences the construction of understandings and problem solving by the group (Hackling, 2003). Success of a group effort also requires interpersonal and social skills of the group members (Hackling, 2003; Johnson \& Johnson, 1999). According to Hackling (2003), these social skills help teachers to manage the group work, to function as cohesive social units, and to enhance cognitive learning outcomes.

The abovementioned review of contemporary literature highlights some of the major concerns regarding learning science in small group. An overview of this discussion mainly reveals two approaches in group learning - cooperative and collaborative, which are somehow considered as an influencing factor in group composition, norms and discourse, and nature of interaction within a group. Besides, prescribed group roles and practicing 
social skills can be considered as an important factor to make a group more effective. All of these concerns are included in the analytical frame of our intended study by adapting a methodology as follows.

\section{Aims and Objectives}

This case study aims to explore science students' perceptions about the nature of ongoing small group activities at the Institute of Education and Research [IER], University of Dhaka. To analyse the students' responses, we considered different aspects of learning in small groups including the approach in group learning, factors influencing the group activities and the nature of students' discourse and norms of participation in groups. In particular, objectives of this study is to

a) find out students' preference in small group learning approaches

b) examine how different factors influence learning in a small group activity

c) explore what social skills students like to practice in working within a small group.

\section{Methodology}

\section{Research Design}

This study followed a mixed model research design integrating both quantitative and qualitative approaches. A mixed research design allows a better understanding of a research problem compared to either qualitative or quantitative data itself (Creswell, 2008; Gay, Mills, \& Airasian, 2006). Quantitative approach primarily provides a scanned description of an issue, whereas qualitative approach is more focused on the exploration and understanding of an issue. It is essential to use the mixed model design because the current study required a description, explanation as well as an understanding of the nature and discourse of group activities from the student's views, which provided with an opportunity to understand the participants' opinions with respect to relevant variables of the study.

\section{Instrument}

Consistent with the research design, both quantitative and qualitative data were collected concurrently to understand the nature of small group learning in science education through a questionnaire. Consequently, the questionnaire included closed-ended, open-ended and mixed-type questions. Open-ended items were included to get a more detailed perspective from the students. We did not anticipate any answer to such questions; rather we intended to get responses in students' words. In mixed-type questions, we leave some space for students to write down their additional comment in words followed by some prescribed options. For these reasons, the language of the questionnaire was set in Bangla (the official language of Bangladesh) as we anticipated that students will feel more comfortable both in understanding the questions and expressing their perspectives in their own language Bangla.

In aligned with the objectives of this research, the questionnaire items addressed three aspects: students' preference in learning approach, influencing factors of students' group learning and the social skills students like to practice in working within a small group. 30 items were included in this questionnaire to address these aspects whereas five items addressed the first aspect, 24 items dealt with the second one and one checklist concentrated on the third aspect. 
To address students' preference in learning approach, we provided a context of a small group activity. Then we asked students to select which approach they preferred in performing such a group work. As well, we provided some possible reasons for their selection and asked students to rate these on a five point Likert scale ranging from "strongly agree" to "strongly disagree" with a mid-point "undecided". This was done basically to help students indicate to what extent $\mathrm{s} /$ he agrees with a statement, such as "cooperative approach provides students more opportunity to work deeply" or "collaborative approach gives a scope to raise different opinion". Altogether three Likert scale items were included in the questionnaire.

In examining how different factors influence learning in a small group activity, we set different items regarding group composition, norms, tasks, students' participation and teacher's guidance. Some of these items required students to choose multiple responses rather than a single one. We also placed some other questions which allowed students to write down their reason along with respective selection. For example, students were asked to mention their preference in deciding about the group task. We provided three possible answers to this question: students will select group task by themselves, teachers will select the task, and group task will be selected by the mutual understanding of teacher and students. In this case, students were allowed to choose more than one response among these three and then allowed to exemplify their response.

In exploring social skills, students were asked to reflect on their practice from a list of 12 aspects of social skills. In this case, they were offered to choose only those skills they usually practice in group work. To name a few, these skills include doing the tasks sincerely, not to interrupting others, praising each other for their contribution and encouraging others to participate.

\section{Expert Opinion and Piloting}

The questionnaire used in this research was developed after synthesising the ideas present in the existing literature regarding learning science in small group. A senior Science Education Professor from IER checked the language and any ambiguity in the questionnaire. According to his suggestion, the item number 2 and 4 in the questionnaire (reasons for preferences) were changed from multiple responses to five-point Likert scale. Further, before administering, the questionnaire was piloted among five students of Science Education group in IER.

\section{Population and Sample}

We considered students of the Science Education group as a case to explore in this study. Data in this study was collected from the students of both the Bachelor of Education (Honours) and Master of Education programs of the Science Education group at IER. All current students of Science Education group (226 in total) from all the current batches $\left(9^{\text {th }}-\right.$ $15^{\text {th }}$ ) were invited to participate in this study voluntarily. 166 students, including 84 males and 82 females agreed to participate finally.

\section{Data Analysis Procedure}

We analyzed quantitative data using the Statistical Package for the Social Sciences (SPSS), version 16.0 for Windows. For example, we asked students to indicate their preferred approach in small group learning. Frequencies of their responses were counted and then presented in terms of percentage for interpreting the results. 
For analyzing qualitative data, we employed "data transformation" procedure (Creswell, 2009). In this procedure, qualitative data were coded according to themes; codes were then assigned to numbers and the frequency of codes appeared were counted to get a numerical data to be presented in this research. For example, students' responses to the question "what do you do if debate arises while working in a group" emerge four themes: (a) arguing with logic and evidence for a consensus by co-constructing ideas, (b) trying to establish one's logic, if it is not accepted in the group, then give up, (c) going for the opinion with majority in the group, and (d) trying to establish their ideas at any cost. We then counted the frequencies for each individual theme from participants' response. Results were then interpreted in terms of percentages as quantitative data. Moreover, quantitative and qualitative data were triangulated to validate the participants' responses.

Table 1

Students' Preferred Approach in Group Work

\begin{tabular}{lll}
\hline Gender & Cooperative & Collaborative \\
\hline Male & 43 & 41 \\
Female & 47 & 35 \\
Total & $90(54.2 \%)$ & $76(45.8 \%)$ \\
\hline
\end{tabular}

\section{Results and Discussion}

The results are reported in three distinct sections: (a) approaches in group learning, (b) influencing factors of group learning, and (c) social skills.

\section{Approaches in Group Learning}

Students were asked whether they prefer cooperative or collaborative approach in group learning. Their responses are summarized in Table 1.

Data in Table 1 may indicate that a higher number of students prefer cooperative approach to collaborative approach for science learning within a small group. In particular, female students mostly prefer cooperative approach compared to their male counterparts. As majority of the students seemed to prefer cooperative approach in working within a small group, it is expected that these students may have a higher academic achievement. As well, greater psychological health, higher self-esteem, and greater social competencies may also be expected from those students as suggested by Johnson and Johnson (1999). As 45.8\% students prefer collaborative approach, it may be reasonable to consider that these students are more able to be involved in problem solving, and more equipped in transferring the knowledge and skills, and hence working as effective team members in line with what is suggested by the literature (e.g., Dickinson, 2000; Kapp, 2009) discussed earlier.

As there are perceived differences in students' preferences in working within a small group, it is necessary to know why they prefer a particular approach as well as the degree of their preference. As discussed previously, a five point Likert scale was used in this regard. The following sections discuss with the rationale of students' preferences.

Cooperative Approach. Data in Table 2 presents the extent of students' likeness to the rationale of their preferences in cooperative approach. It seems apparent from data in Table 2 that students characterize cooperative approach having more opportunity to work deeply followed by the notion of increasing the quality of work because of individual expertise. Also, more than half of the students agreed to the notion that cooperative approach gives 
students a good feeling because of taking less responsibility. While almost half of the students $(48.8 \%)$ did not consider 'opportunity to freedom of work' as a reason for choosing cooperative approach. Therefore it can be concluded from students' perspectives that they prefer cooperative approach for working intensively with individual expertise that may improve the quality of group work.

Table 2

Rationale of Students' Preferences in Cooperative Approach

\begin{tabular}{lccccc}
\hline Cooperative Approach & SA (\%) & $\mathrm{A}(\%)$ & $\mathrm{U}(\%)$ & $\mathrm{D}(\%)$ & $\mathrm{SD}(\%)$ \\
\hline $\begin{array}{l}\text { provides students more opportunity to work } \\
\quad \text { deeply }\end{array}$ & 79.5 & 18.1 & 2.4 & - & - \\
$\begin{array}{l}\text { increase the quality of work, because the task } \\
\quad \begin{array}{l}\text { can be distributed according to } \\
\text { individual's skill }\end{array}\end{array}$ & 45.5 & 43.2 & 9.1 & 1.1 & 1.1 \\
$\begin{array}{l}\text { gives more output in less time and labor } \\
\quad\end{array}$ & 36.0 & 41.5 & 14.6 & 4.5 & 3.4 \\
$\begin{array}{l}\text { gives a good feeling to students because of } \\
\quad \text { taking less responsibility }\end{array}$ & 26.2 & 25.0 & 17.0 & 15.9 & 15.9 \\
provides students a freedom of work & 17.0 & 16.0 & 18.2 & 13.6 & 35.2 \\
\hline
\end{tabular}

The percentages are calculated among the respondents who preferred cooperative approach. $\mathrm{SA}=$ Strongly agree; $\mathrm{A}=$ Agree: $\mathrm{U}=$ Undecided $; \mathrm{D}=$ Disagree; $\mathrm{SD}=$ Strongly disagree

Collaborative Approach. Data in Table 3 presents the extent of students' likeness to the rationale of their preferences in collaborative approach. Table 3 appears to indicate that students who prefer collaborative approach considered opportunities to co-construct their naïve ideas as a very strong reason $(90.6 \%)$. Students also considered opportunity to build overall scanned ideas on the entire topic from this approach as another very strong reason (89.9\%) in preferring the collaborative approach. These results seem to indicate that the students who prefer collaborative approach are likely to be involved in constructivist learning.

Table 3

Rationale of Students' Preferences in Collaborative Approach

\begin{tabular}{llllll}
\hline Collaborative approach & SA (\%) & A (\%) & U (\%) & D (\%) SD (\%) \\
$\begin{array}{l}\text { provides students an opportunity to build their } \\
\quad \begin{array}{l}\text { ideas on entire topic } \\
\text { gives a scope to raise different opinion }\end{array}\end{array}$ & 60.9 & 29.0 & 8.7 & - & 1.4 \\
$\begin{array}{l}\text { make students co-construct their ideas, hence a } \\
\text { clarity in understanding is possible }\end{array}$ & 60.0 & 30.6 & 6.7 & 2.7 & - \\
\hline
\end{tabular}

The percentages are calculated among the respondents who preferred collaborative approach. $\mathrm{SA}=$ Strongly agree; $\mathrm{A}=$ Agree: $\mathrm{U}=$ Undecided; $\mathrm{D}=$ Disagree; $\mathrm{SD}=$ Strongly disagree

Students also identified the difficulties they faced in adopting the cooperative and collaborative approach. Most of the students who preferred the cooperative approach had experienced that some group members do not give enough effort. Also, the majority of 
students faced difficulty in distributing the task when more than one person liked to do the same task. One of the students commented as follows:

In many cases, more than one person likes to do the same job; it is really difficult to coordinate according to individual's choice.

Hence the task lacks adequate information and the quality of the work correspondingly deteriorates. As a result, these students might pose lack of trust in their cohort that may lead to misunderstand other's perspectives as suggested by Johnson and Johnson (1999).

As well, students who prefer collaborative approach, also face some difficulties. To name a few, these difficulties include overlapping information collected by different members, students' tendency to copying others' work, and lack of time. Some students stress that they are supposed to do lots of work in following the collaborative approach, which deteriorates the quality of work. One such response is as follows:

We have to search references for the entire assignment topic; it is plenty of work. So it is natural that we cannot explore the problem in depth.

The abovementioned difficulties in adapting collaborative approach might not lead students to be motivated intrinsically; also it might not persist with adversity and be unable to transfer knowledge and skills to other group members as suggested by previous research (e.g., Kapp, 2009; Pfaff \& Huddleston, 2003).

\section{Influencing Factors in Group Learning}

This section deals with Group Composition, Group Norms, Group Task, Nature of the Group Task, Student Participation, and Teacher Guidance as the factors that influence group learning.

Group Composition. More than half of the students $(58.4 \%)$ opine that the groups are usually formed by the mutual understanding between themselves and respective teachers. In some cases $(29.5 \%)$, students are allowed to form groups by their own choice. Students were asked to mention their consideration when building groups by themselves. Their responses were summarized as in Table 4.

Table 4

Student's Consideration in Building Group Themselves

\begin{tabular}{lr}
\hline Having opportunity to take more responsibility & $4.1 \%$ \\
Having less responsibility & $21.1 \%$ \\
Having opportunity to apply own intellect & $35.5 \%$ \\
Having opportunity to choose task by themselves & $6.6 \%$ \\
Having opportunity to work independently & $8.5 \%$ \\
Sincere and friendly team mate & $24.2 \%$ \\
\hline
\end{tabular}

Data in Table 4 show, the highest portion of students $(35.5 \%)$ likes to be involved in a group where they may have more opportunity to apply their intellect and expertise. As well, a considerable number of students $(21.1 \%)$ prefer the group where they will have less responsibility. Sincere and friendly teammates are also a concern for a considerable number of students $(24.2 \%)$. One of the students commented as follows:

I feel comfortable in a group where the members are sincere, friendly and where everybody can share the work equally. 
A small number of students $(8.5 \%)$ considered whether they had the opportunity to work independently within a group.

I prefer a group where I can work independently and do not prefer those who like to dominate the group members.

Some of the reasons presented above might be aligned with the characteristics of cooperative approach, while some others are consistent with collaborative approach. Therefore, students might not feel comfortable in working with their group because of their different choices. However, if they are insisted upon to work as a group, some members may not be satisfied in working with each other within the group. This concurs with our experiences in involving teaching-learning processes at IER.

In response to the ability concern in group composition to make the group work successful, the majority of the students $(71.7 \%)$ opine that they prefer a group with a mixing of high and low ability students, while some students $(15.1 \%)$ prefer a group consisting of high, mid and low ability students. While the majority of the participant students find a group more successful with a composition of high and low-ability students, it seems to be at odds with the group compositions what Blumenfeld, et al. (1996) suggested for the success of a group work.

We have also experienced that students at IER tend to belong to the same group though the tasks are different. This experience triggered our interests to explore students' considerations in this regard. Students' responses appeared to suggest that more than half of them $(53 \%)$ always liked to work with the same cohort, because they thought it was convenient to work with the members who already had an established understanding with each other. In contrast, a large number of students $(45.8 \%)$ did not like to work with the same members as they thought working with different members could bring variation in the task. As well, it gave an opportunity to know others who they did not know well, which helped to learn new things/ideas from new group members. The abovementioned result suggests that there are two distinct types of students at IER in choosing the same cohort every time. Therefore, it is rational to argue that if a group is formed by selecting members from these two distinct types, some members may feel upset in working within the group.

Group Norms. As previously discussed, effective group work requires students to follow some norms, such as how they behave if a conflict in ideas arises and how they generate everyone's point of view. Students' responses indicate that they (84.94\%) usually argue with logic and evidence, listen to other's opinions and finally negotiate to come to a consensus by co-constructing ideas where needed. This result again confirms students' preference to constructivist learning. As there are some students $(3.62 \%)$ who avoid such kind of argumentation and usually go for the opinion with majority in the group, they are likely to avoid conflicts as suggested by Blumenfeld, et al. (1996). However, another small number of students $(3.62 \%)$ argue that they want to establish their ideas at any cost. This also concurs with existing literature discussed earlier.

Group Task. Teachers play the dominant role in deciding about the group task at IER. We come to this conclusion because the majority of the students $(71.7 \%)$ said that decision about the group assignment topic is made by the teachers (see Table 5). 
However we liked to know what the students actually prefer. Most of the students $(83.2 \%)$ opine that they prefer students and teachers to mutually decide the group task (see Table 5). A student's comment reflects this view as,

By negotiating with each other [teacher and student], students' interest for the task

remains positive, hence it is possible to produce a quality work.

This preference for mutuality reflects that the integration between teacher's experiences and student's interest is possible if and only if both teachers and students take the decision.

While a small number of them $(9.6 \%)$ like to choose the group task by their own that help them to reduce "social loafing" after Carroll (1986) and Harkins and Petty (1982).

Table 5

Decision About the Group Task

\begin{tabular}{lcc}
\hline Decision made by & Ongoing practice in IER (\%) & Student's preferences (\%) \\
\hline Teachers & 71.7 & 7.2 \\
Students & 1.2 & 9.6 \\
Mutual understanding between & 27.1 & 83.2 \\
teachers and students & & \\
\hline
\end{tabular}

Nature of the Group Task. The nature of the group task was also explored in this study. More than half of the students $(51.9 \%)$ consider their group task as life-oriented, while the rest $(48.1 \%)$ consider their group task as something that is often far away from their life contexts. Here are some comments which seem to be very thought-provoking to us.

The group task is often curriculum related, but is the curriculum life oriented?

Our teachers do not think enough to give such assignments which would be life related.

In many cases, I do not see the relation of science with real life; hence there is not enough opportunity for that [life-oriented task].

The first two comments are related to curriculum of IER and teachers' commitment, while the last comment is very significant in terms of the students' perception of science. Literature reveals that in many cases, school students do not find their school science relevant to their life (Jenkins, 2006; Lindahl, 2003; Lyons, 2006a, 2006b; Osborne \& Collins, 2001). The comment in our study appears to indicate that students' such perceptions about school science also prevail up to their higher studies.

Most of the students $(80.4 \%)$ consider that the group tasks provide with opportunities to nurture their creativity. At this point, many of them opine that they often do different project works and present them in different ways, for example, by the PowerPoint slides and posters, which may provide them with an opportunity to cherish their creativity. Also, tasks like preparing teaching-learning aids, bulletin boards and models are mentioned by the students, which leave with enough scope for creativity. However, some students (19.6\%) think their group work does not involve their creativity. One such comment is as follows.

The assigned tasks are traditionally structured. I can do it using the textbooks or just following a senior student's previous work.

The above results suggest us to argue that the most ongoing small group work at IER include students' creativity that allows them to work in multiple ways in examining an 
issue. As well, this may also allows them to reach to more than one answer to a particular task.

Table 6

Participation of Group Members

All members equally participate

$19.2 \%$

All members participate, but the participation is not equal

$60.6 \%$

One member takes most of the responsibilities

$6.0 \%$

Some members do not participate at all

$14.2 \%$

Student Participation. Data in Table 6 show the ongoing practice of students' participation in small group activity in IER.

The majority of the students $(60.6 \%)$ opine that every member in a group tends to participate, however their participation is not equal. While, a considerable number of students (19.2\%) experienced that all the members participated equally, some (14.2\%) founds that there are some students who do not participate at all. These results indicate that students often do not participate equally in their group work, which does not ensure individual's accountability after Johnson and Johnson (1999). This trend is also more or less similar to what we experienced in our student life.

Students' participation in a group may include how they take part in the group discussion. A variety of practices among students is found in this regard. Students' responses reveal that in some cases, each and every group member discusses separately (7.6\%), while sometimes one member discusses with the assistance of others (11.5\%). However, in most cases $(78.4 \%)$, one member presents the main theme and then the discussion progresses. Students' ideas are co-constructed through such a discussion. The above findings reflect that in some cases, students like to be involved in symmetric interaction with collaborative and adversarial mode. However most of the students' participation in group discussion promoted them to be involving in asymmetric interaction that is consistent with our experiences of group work.

We also intended to know what things students considered when group discussion proceeds. The majority of the students $(70.65 \%)$ consider that group discussion mostly extensive and relevant with the task. A small number of students (16.15\%) consider the equal participation from the group members. These considerations of the students reveal that the nature of students' interactions in a group mostly encourages mutuality as suggested by Demon and Phelps (1989).

Students' perspectives on assessment of group activities were also explored within this study. Most of the students $(81 \%)$ opine that student's individual contribution should be counted in conjunction with group performance. However, some other (19\%) opines that group assessment should be solely based on group performance. These findings also concur with our experiences what lead to students' dissatisfaction after getting a single grade for a group task.

Students were asked to visualize the best roles of the group members that can render a task successful. Most of the students (45.8\%) visualize the role of group members in a group of four people as follows:

Member 1: will communicate, lead the group and collect references

Member 2: will collect all the information

Member 3: will coordinate and analyze all the information

Member 4: will be responsible for documentation and presenting the result 
Students' visualizations presented above are aligned with the four group roles as suggested by Hackling (2003), which may help participants to manage and organize the group work. This may also influence group work for a better construction of understanding.

Teacher Guidance. The majority of the students $(60.5 \%)$ opine that the teachers instruct properly when involving students in group work. However a good number of them (39.5\%) express that teachers' instructions are not appropriate. Some students find that the teachers expect too much without giving enough guidance. One of such a student's comments is as follows.

There is a huge gap between teacher's instruction and what she expects.

While almost all the students (95.2\%) see teachers' instruction as very important, a minority of them (4.8\%) do not like such instructions:

If I am allowed to work according to my own [instead of according to teacher's guidance], I can best utilize my creativity and merit.

The above results indicate that students are divided into two groups regarding the issue of teacher's guidance. Therefore it seems to be very difficult to conclude whether students of IER get enough guidance from their teachers in the process of argumentation and justification for their reasoning as most of them expected adequate guidance from their teachers.

Table 7

Social Skills Practiced in Small Group Work

\begin{tabular}{lc}
\hline Students- & $\%$ \\
\hline behave politely with each other in a group & 72.28 \\
stand in different positions with others' point of view but not with the person & 69.89 \\
encourage others to contribute & 68.07 \\
do not interrupt each other and let finish their assigned task & 67.47 \\
generate alternative ideas and explanations where necessary and accept ideas & 63.25 \\
$\quad$ most relevant one with available data & 61.45 \\
do the tasks sincerely & 59.03 \\
praise each other for their contribution & 40.96 \\
acknowledge others for their contribution & 58.43 \\
make sure that every individual in the group can get an understanding of the & \\
$\quad$ task & 22.89 \\
\hline
\end{tabular}

Social Skills

We also explored what social skills students exercise while working within a group. Students' responses in this respect are summarized in Table 7.

Data in Table 7 indicate that a majority of students practice acceptable social skills when they are involved in group activities. Students' practice presented in Table 7 suggests us to argue that these skills can help a group to function as cohesive social units. As well, these can enhance students' cognitive learning outcomes. However, we anticipate form data in the table that a large number of students do not have an attitude to acknowledge others for 
their contribution. Also, a large number of students do not think that they participate actively but quietly in the group. This finding also concurs with our experiences.

The above results indicate that the reason for students' preference in group learning may have a correlation with the influencing factors of group learning, such as group composition, task, participation and social skills. It is evident that students' considerations for group formation relates with the reasons for students' preference (Setiawan \& Mufassaroh, 2019). For example, having opportunity to con-construct ideas was a strong reason for preferring a group approach which was also a consideration for students' group formation. Similarly, issue for taking less responsibility was considered by the students in both of their preferring group learning approach and deliberation of group composition (Setiawan, 2020a).

The findings of this study reveals that students' preference in learning approach may have relevance with the group task (Setiawan, 2020b). For example, students usually do not like to decide their task independently; rather they prefer mutual understanding with their teachers. This finding seems to be consistent with the notion that majority of the students do not consider 'freedom of work' a strong reason for preferring group learning approach.

In exploring students' participation in group, we found that most students like to be involved in a way where one student presents the main theme and then the discussion progresses (Setiawan, 2017). Such a progression in discussion could be viewed as aligned with the co-construction of ideas that was considered as a strong reason in preferring an approach in group learning.

This study also exposes various social skills practiced by the group members. Some of these skills align with their preference for the group learning approach. For example, students practice the skill of 'doing the task sincerely' that may imply to their preference for the opportunity to work deeply in cooperative approach.

\section{Conclusion and Implications}

We have found in this study that every student do not like the same approach in group learning; some of them prefer cooperative approach, while some others prefer collaborative approach. So, when students at IER form groups to perform a task, both teachers and students need to be concerned about the student's individual preference in group learning. If student's individual preference is counted in selecting groups, it may be rational to expect more students' satisfaction, and hence a better outcome from the group may possible.

This study also finds that most of the students of IER prefer a group with a mixing of high and low ability students. This finding is not consistent with literature discussed earlier. However we would argue that the difference in context may be a reason for this inconsistency. Therefore further research is recommended in this respect.

While in most cases teachers and students mutually decide about the composition of group, teachers dominate in deciding about the group task at IER. However students stress that if teachers and students mutually decide about the group task similarly as group composition, teachers' experiences and students' interests could be better integrated. We concur with their perspectives. Therefore, it is reasonable to suggest to teachers of IER to be more concerned in making decision about the group task. Also, as this research reveals, a significant number of students $(39.5 \%)$ find the teacher's guidance as inadequate in preparing the group task, teachers need to be more focused on providing with appropriate guidance and may monitor the group to make the activity a fruitful one. 
Findings of this study also reveal that students' nature of participation is dominated by asymmetric interaction. Besides, at IER, a same grade usually goes to all of the group members regardless of individual contribution. These practices may not ensure everyone's accountability to the group. It could be concluded that to ensure individual's accountability teachers need to be concerned whether students can be involved in any other approach for group interaction (e.g., symmetric, shifting asymmetric) or assess individual performance within a group.

This paper explores the nature of small group learning from students' perspectives. Many of the findings of this research trigger our thinking to know these issues from teachers' perspectives. Further research is recommended in this respect.

\section{References}

Blumenfeld, P. C., Marx, R. W., Soloway, E. \& Krajcik, J. (1996). Learning with peers: From small group cooperation to collaborative communities. Educational Researcher, 25(8), 37-40.

Brewer, S. \& Klein, J. D. (2006). Type of positive interdependence and affiliation motive in an asynshronous, collaborative learning environment. Educational Technology Research and Development, 54(4), 331-354.

Brown, G. \& Atkins, M. (1991). Effective teaching in higher education. London: Routledge. Carlsmith, K. M. \& Cooper, J. (2002). A persuasive example of collaborative learning. Teaching of Psychology, 29(2), 132-135.

Carroll, D. W. (1986). Use of the jigsaw technique in laboratory and discussion classes. Teaching of Psychology, 13, 208-210.

Creswell, J. W. (2008). Educational research: Planning, conducting, and evaluating quantitative and qualitative research (3rd ed.). New Jersey: Pearson Education, Inc.

Creswell, J. W. (2009). Research design: Qualitative, quantitative, and mixed methods approaches (3rd ed.). LA: SAGE.

Crook, C. (1994). Computer and the collaborative experience of learning. London: Routledge.

Damon, W. \& Phelps, E. (1989). Critical distinctions among three approaches to peer education. International Journal of Educational Research, 13, 9-19.

Dickinson, M. (2000). Giving undergraduates meaningful experience. Education and Training, 42, 159-170.

Driver, R., Leach, J., Millar, R. \& Scott, P. (1996). Young peoples images of science. Bristol: Open University Press.

Duek, J. E. (2000). Whose group is it, anyway? Equity of student discourse in problembased learning (PBL). In D. H. Evensen \& C. E. Hmelo (Eds.), Problem based learning: A research perspective on learning interactions (pp. 75-107). Mahwah, NJ: Lawrence Erlbaum Associates.

Gay, L. R., Mills, G. E. \& Airasian, P. (2006). Educational research: Competencies for analysis and applications (8th ed.). Upper Saddle River: Pearson Merrill Prentice Hall.

Hackling, M. (2003). Current issues in science education: Guide. Edith Cowan University, Perth, Australia.

Harkins, S. G. \& Petty, R. E. (1982). Effects of task difficulty and task uniqueness on social loafing. Journal of Personality and Social Psychology, 43, 1214-1229.

Hendry, G. D., Heinrich, P., Lyon, P. M., Barratt, A. L., Simpson, J. M., Hyde, S. J., et al. (2005). Helping students understand their learning styles: Effects on study seelf- 
efficacy, preference for group work, and group climate. Educational Psychology, 25(4), 395-407.

Houldsworth, C. \& Mathews, B. P. (2000). Group composition, performance and educational attainment. Education and Training, 42, 50-53.

Jenkins, E. W. (2006). Student opinion in England about science and technology. Research in Science \& Technological Education, 24(1), 59-68.

Johnson, D. W. \& Johnson, R. T. (1999). Making cooperative learning work. Theory into Practice, 38(2), 67-73.

Kapp, E. (2009). Improving student teamwork in a collaborative project-based course. College Teaching, 57(3), 139-143.

Kempa, R. F. \& Ayob, A. (1995). Learning from group work in science. International Journal of Science Education, 17(6), 743-754.

Lindahl, B. (2003). Pupils' responses to school science and technology? A longitudial pathway to uppersecondary school. A summary of my thesis Retrieved 2 August, 2009, from http://na-serv.did.gu.se/avhand/lindahl.pdf

Linn, M. C. \& Burbules, N. C. (1993). Construction of knowledge and group learning. In K. Tobin (Ed.), The practice of constructivism in science education (pp. 91-119). Washington DC: American Association for the Advancement of Sciene.

Lyons, T. (2006a). Different countries, same science classes: Students' experiences of school science in their own words. International Journal of Science Education, 28(6), 591-613.

Lyons, T. (2006b). The puzzle of falling enrolments in Physics and Chemistry courses: Putting some pieces together. Research in Science Education, 36, 285-311.

Millis, B. \& Cottell, P. G. (1998). Cooperative learning for higher education faculty. Westport, CT: American Council of Education.

Osborne, J. \& Collins, S. (2001). Pupils' views of the role and value of the science curriculum: A focus-group study. International Journal of Science Education, 23(5), 441-467.

Palincsar, A. S., Anderson, C. A. \& David, Y. M. (1993). Pursuing scientific literacy in the middle grades through collaborative problem solving. Elementary School Journal, 93(5), 643-658.

Pfaff, E. \& Huddleston, P. (2003). Does it matter if I hate teamwork? What impacts student attitudes toward teamwork. Journal of Marketing Education, 25(1), 37-45.

Richmond, G. \& Striley, J. (1996). Making meaning in classrooms: Social processes in small-group discourse and scienctific knowledge building. Research in Science Education, 33(8), 839-858.

Setiawan, Adib Rifqi. (2020a). Pembelajaran Tematik Berorientasi Literasi Saintifik. Jurnal Basicedu: Journal of Elementary Education, 04(01): 71-80. URL: https://jbasic.org/index.php/basicedu/article/view/298

Setiawan, Adib Rifqi. (2020b). Pendidikan Literasi Finansial Melalui Pembelajaran Fiqh Mu'āmalāt Berbasis Kitab Kuning. Nazhruna: Jurnal Pendidikan Islam, 03(01): 138159. URL: http://e-journal.ikhac.ac.id/index.php/NAZHRUNA/article/view/522

Setiawan, Adib Rifqi; Mufassaroh, Arij Zulfi. (2019). Menyusun Soal Literasi Saintifik untuk Pembelajaran Biologi Topik Plantae dan Animalia. BIOSFER: Jurnal Biologi dan Pendidikan Biologi, 04(01): 33-40. URL: http://dx.doi.org/10.23969/biosfer.v4i1.1484

Setiawan, Adib Rifqi. (2017). Penerapan Pendekatan Saintifik untuk Melatihkan Literasi Saintifik dalam Domain Kompetensi pada Topik Gerak Lurus di Sekolah Menengah 
Pertama. Undergraduate Thesis. Bandung: Universitas Pendidikan Indonesia. URL: http://repository.upi.edu/29074/

The Curriculum Committee (2006). Curriculum: Four-year Bachelor of Education (Honours) - An integrated program of general and professional education (2nd [Revised] ed.). Dhaka: Institute of Education and Research [IER], University of Dhaka. Thomas, S. \& Busby, S. (2003). Do industry collaborative projects enhance student earning? Education \& Training, 45, 226-235.

Webb, N. M. \& Mastergeorge, A. M. (2003). The development of students' helping behavior and learning in peer-directed small groups. International Journal of Educational Research, 21(4), 361-428. 